\title{
MELESTARIKAN BUDAYA LITERASI KARYA SASTRA MELALUI LITERASI DIGITAL DI ERA MILENIAL
}

\author{
Muthoharoh $^{1}$ Hasti Prastyaningsih ${ }^{2}$ \\ Universitas Muhammadiyah Tangerang \\ muthoharoh@gmail.com ${ }^{1}$ \\ hasti.prastya26@gmail.com²
}

\begin{abstract}
Abstrak
Perkembangan teknologi yang semakin canggih menawarkan berbagai macam sajian informasi. Masuknya teknologi internet juga menjadikan media informasi semakin beragam. Media internet menjadikan masyarakat konsumtif terhadap berbagai hal, salat satunya media sosial. Hal tersebut membuka peluang bagi oknum yang tidak bertanggungjawab untuk menyebarkan berita-berita hoax. Maka, diperlukan keterlitian bagi masyarakat dalam menyaring informasi. Oleh karena itu, gerakan literasi digital diperlukan dalam memupuk budaya literasi. Kegiatan literasi digital diharapkan dipupuk sejak dini dengan memberikan literasi digital karya sastra kepada anak-anak. Para orang tua diharapkan mampu memanfaatkan karya sastra digital dalam mengajarkan budaya literasi digital. Maka, masyarakat akan tumbuh menjadi masyarakat yang kritis dan kaya pengetahuan.
\end{abstract}

Kata Kunci: Karya Sastra, Literasi Digital

\section{A. PENDAHULUAN}

Literasi merupakan suatu kemampuan individu dalam mengolah dan memahami informasi ketika melakukan kegiatan membaca dan menulis. Dengan kata lain, literasi adalah seperangkat keterampilan dan kemampuan seseorang dalam membaca, menulis, serta memecahkan masalah dalam kehidupannya sehari-hari. Seseorang dengan kemampuan literasi yang baik akan mampu mendapatkan dan menggunakan informasi secara efisien dan efektif, mengevaluasi informasi secara kritis dan sesuai dengan kompetensinya, serta mampu menggunakan informasi yang didapat secara akurat dan kreatif. daya literasi sangat dibutuhkan sebagai kekuatan dalam menanamkan budaya literasi pada diri sendiri. Daya literasi yaitu kekuatan menggunakan dan memanfaatkan berbagai hal untuk mengembangkan pengetahuan, keterampilan dan sikap ditandai dengan berbagai aktivitas positif seperti membaca, menyimak, menulis, dan berbicara. Daya literasi ini dapat dilihat dari berbagai komponen literasi informasi.

Akan tetapi, budaya literasi pada era milenial semakin ditinggalkan. Masyarakat yang dimanjakan oleh teknologi yang serba instan, cenderung menjadi masyarakat yang suka hal- 
hal instant. Misalnya, mereka lebih suka menonton film daripada membaca buku, mereka lebih suka bermain handphone daripada membaca buku. Maka, ketika berita-berita hoax yang beredar, masyarakat dengan mudah percaya karena mereka tidak mempunyai inisiatif unruk mencari kebenarannya dengan cara membaca. Maka, budaya literasi Indonesia menjadi semakin tertinggal dengan negara lain.

Kebiasaan membaca sangat penting. Namun, beberapa kendala dan alasan biasanya diungkapkan karena malas dan isi karya sastra yang kurang menarik. Hal ini membuat budaya literasi di era milenial semakin mengkhawatirkan sebab minimnya kesadaran akan budaya berliterasi terhadap karya sastra yang ada. Kebanyakan membaca ketika ada perlunya saja, sehingga saat ini berkurangnya karya-karya sastra baru yang dihasilkan oleh generasigenerasi penerus bangsa di era milenial. Faktor lain yang memengaruhi rendahnya literasi adalah kurangnya motivasi dan keingintahuan padahal dengan membaca kita dapat membuka jendela-jendela ilmu pengetahuan. Seseorang pasti mendapatkan informasi-informasi yang lebih akurat dan tidak diragukan lagi.

Iklan-iklan yang banyak mengeksploitasi tubuh perempuan, sinetron-sinetron menjual mimpi, game online yang membius, konten-konten media sosial seperti face book, youtube, instagram, tweeter, whatshap, line dan sebagainya yang sangat memikat sehingga dapat menghipnotis khalayaknya. Mereka menciptakan budaya ketergantungan bagi khalayaknya. Dengan demikian budaya buruk ini harus diantisipasi dengan budaya literasi media. Literasi media perlu disosialisasikan secara terus menerus kepada masyarakat sampai mereka betulbetul menyadari bagaimana cara mengkonsumsi media dengan benar (Novianti, 2019:220).

Budaya literasi harus dipupuk sejak dini, dari para orang tua di lingkungan keluarga. Para orang tua seharusnya mengajarkan anak-anak mereka untuk senang membaca di rumah. Salah satu cara dalam meningkatkan budaya literasi di rumah yaitu dengan memberikan bacaan karya sastra. Oleh karena, anak-anak suka dengan bacaan-bacaan yang berkarakter. Karya sastra memiliki unsur-unsur intrinsik yang dapat membuat anak seolah-olah ikut andil dalam alur cerita yang diciptakan di dalam karya sastra. Tokoh-tokoh yang digambarkan dengan watak-watak protagonis dapat mencuri perhatian anak sehingga anak dapat meneladani sikap-sikap yang digambarkan oleh tokoh.

\section{B. Budaya Literasi dan Literasi Digital}


Literasi merupakan suatu kemampuan yang dimiliki oleh setiap individu untuk dapat menggunakan potensi serta keterampilan dalam mengolah dan juga memahami informasi saat melakukan kegiatan atau aktivitas membaca dan menulis. Hal tersebut merupakan konsep awal literasi. Namun, literasi berkembang tidak hanya membaca dan menulis, literasi merupakan kemampuan manusia dalam mengkomunikasikan segala informasi denagn sesama manusia (Windarti, 2018:49). Literasi sangat banyak sekali manfaatnya, salah satu keuntungan dari literasi ini diantaranya adalah dapat melatih diri untuk dapat lebih terbiasa dalam membaca serta juga dapat membiasakan seseorang untuk dapat menyerap informasi yang dibaca dan dirangkum dengan menggunakan bahasa yang dipahami. Dengan berliterasi, dapat membantu meningkatkan wawasan serta pengetahuan seseorang dalam menggunakan informasi secara efektif dan efisien.

Sedangkan literasi digital merupakan pemanfaatan media digital sebagai upaya dalam mewujudkan budaya literasi. Digitalisasi merupakan salah satu fenomena perkembangan teknologi yang mengganti bentuk fisik menjadi bentuk berbasis daring (Windarti, 2018:50). Sedangkan literasi digital diartikan sebagai kemampuan individu untuk menerapkan keterampilan fungsional pada perangkkap digital sehingga dapat menemukan dan memilih informasi secara kritis, berkreatifitas, berkolaborasi dengan oranglain, berkomunikasi secara efektif, dan tetap menghiraukan keamanan elektronik serta konteks sosial budaya yang berkembang (Nurlela, Narulita, dan Wajdi, 2018:449-450).

Karakteristik literasi digital tidak hanya mengacu pada keterampilan operasi dan menggunakan berbagai perangkat teknologi informasi dan komunikasi teknologi (perangkat keras dan platform perangkat lunak), tetapi juga untuk proses "membaca" dan "memahami" sajian isi perangkat teknologi serta proses "menciptakan" dan "menulis" menjadi sebuah pengetahuan baru (Kurnianingsih, Rosini, dan Ismayati, 2017:63). Literasi digital memanfaatkan teknologi internet dalam menyampaikan dan mengkomunikasikan kegiatan literasi. literasi digital adalah literasi informasi yang membekali khalayak dengan kemampuan untuk mencerna, memahami, menyeleksi, dan mendapatkan kembali (to retrieve) informasi di tengah banjir informasi yang terjadi (Kurnia dan Astuti, 2017:153).

\section{Upaya Melestarikan Literasi Digital Karya Sastra}

Budaya literasi digital pada saat ini belum dianggap sebagai suatu hal yang penting. Literasi digital adalah jendela dunia yang membuat masyarakat dekat dengan karya sastra, buku, karakter bangsa dan peradaban. Kebiasaan berfikir yang diikuti oleh sebuah proses 
membaca, pada akhirnya dalam kegiatan tersebut menghasilkan suatu karya. Peranan literasi digital memiliki pengaruh besar dalam mengidentifikasi minat masyarakat. Oleh karena transformasi teknologi informasi semakin mudah yang seharusnya menjadikan masyarakat lebih kritis dalam menganalisis informasi (Oktaviani, Aulia, dan Narulita, 2018:587)

Upaya menghadapi pengaruh-pengaruh budaya global yang sangat kuat, diperlukan kesadaran masyarakat harus dapat mengembangkan dan melestarikan budaya literasi karya sastra salah satunya melalui literasi digital. Mengatasi kondisi tersebut bisa dilakukan dengan cara-cara modern, misalnya dengan menambah koleksi artikel karya sastra di web atau blog secara berkesinambungan dan aktual. Namun kegiatan membaca dan menulis bukan lagi persoalan fasilitas semata, tetapi persoalan perilaku. Lantaran masalah perilaku, maka cara yang dapat ditempuh adalah dengan menumbuhkan kesadaran literasi.

Menumbuhkan kesadaran berliterasi memang membutuhkan waktu yang lama, namun harus tetap dijalankan agar tumbuhnya rasa minat dalam berliterasi pada diri seseorang. Misalnya bisa dimulai dari membentuk kegiatan komunitas literasi digital dalam bentuk Klub Baca Karya Sastra atau rumah baca. Jadi strategi dan upaya untuk meningkatkan minat baca di kalangan masyarakat adalah dengan cara membiasakan diri untuk gemar membaca, memiliki target membaca dengan tempo waktu tertentu, memanfaatkan waktu senggang untuk membaca, dan memanfaatkan internet sebagai media literasi digital.

Hal lain yang dapat dilakukan adalah dengan melibatkan pembaca ke dalam penulisan karya sastra, contohnya membuat cerita atau puisi berantai yang melibatkan seluruh pembaca, setiap pembaca berhak memberikan masukkan kelanjutan cerita sehingga pembaca tertarik untuk tetap membaca kelanjutan yang telah mereka berikan. Tentunya tidak keluar dari kaidah, etika, dan norma yang ada sehingga memberikan stimulus kepada pembacanya. Selain itu, dapat dilakukan dengan mengapresiasi karya sastra yang telah dikirimkan kepada satu media massa. Selain itu, dapat dilakukan dengan cara mengunggah kembali hasil karya tersebut ke media sosial lainnya, misalnya youtube. Pembaca diharapkan dapat menikmati karya sastra di berbagai web atau blog dengan kemasan yang berbeda. Karya sastra yang diunggah kembali oleh suatu kelompok di web atau blog membuat penikmatnya semakin termotivasi untuk membaca dan menulis agar karyanya dapat dibaca oleh banyak orang dan memberikan dampak yang baik baik banyak orang.

Ada baiknya jika pembaca khususnya tidak hanya memosisikan dirinya sebagai pembaca atau penulis karya. Akan tetapi, mencoba menjadi pemerhati sastra. Dengan 
demikian, membiasakan kegiatan tersebut masyarakat akan sukses dalam kecerdasan intelektual, emosional, dan spiritual. Apabila sudah menguasai berbagai bacaan dan mampu mengimplementasikan dalam kehidupannya sehari-hari, sehingga dapat meningkatkan literasi digital karya sastra dan terciptanya inovasi baru di dalamnya. Masyarakat dapat menaikkan peringkat literasi Indonesia melalui gerakan budaya membaca, karena membaca adalah pintu gerbang dalam meningkatkan literasi. Dengan membaca, seseorang akan mampu menulis dan berdiskusi. Kebiasaan membaca akan mengantarkan masyarakat menjadi masyarakat yang kaya akan ilmu pengetahuan.

\section{SIMPULAN}

Karya sastra dapat menjadikan sebuah upaya mengajarkan budaya literasi kepada anak-anak. Penggunaan karya sastra oleh para orang tua dapat memotivasi anak-anak untuk gemar membaca dan menulis. Karya sastra yang diterbitkan dalam media web atau blog merupakan upaya menyediaan fasilitas karya sastra yang lebih beragam dan mudah untuk diakses siapa saja. Maka, para orang tua diharapkan mampu memanfaatkan media web atau blog sebagai upaya membentuk budaya literasi digital pada generasi penerus.

\section{E. DAFTAR PUSTAKA}

Kurnia, Novi dan Santi Indra Astuti. 2017. Peta Gerakan Literasi Digital di Indonesia:Studi Tentang Pelaku, Ragam Kegiatan, Kelompok Sasaean dan Mitra yang Dilakukan Oleh $\begin{array}{llllllll}\text { Japelidi. Jurnal Informasi. Vol } 47 & \text { No } 2 & 2017 & \text { Hal }\end{array}$ https://journal.uny.ac.id/index.php/informasi/article/view/16079

Kurnianingsih, Indah, Rosini, dan Nita Ismayati. 2017. Upaya Peningkatan Kemampuan Literasi Digital Bagi Tenaga Pustakawan Sekolah dan Guru di Wilayah Jakarta Pusat Melalui Pelatihan Literasi Informasi. Jurnal Pengabdian Kepada Masyarakat. Vol 3 No 12017 Hal https://jurnal.ugm.ac.id/jpkm/article/view/25370

Novianti, Dewi dan Siti Fatonah. 2019. Budaya Literasi Digital pada Ibu-Ibu Rumah Tangga. Jantro: Jurnal Antropologi:Isu-Isu Sosial Budaya. Vol 21 No 22019 Hal http://jurnalantropologi.fisip.unand.ac.id/index.php/jantro/article/view/149

Nurlela, R. Siti, Sari Nutulita, dan Firdaus Wajdi. 2018. Peranan Literasi Digital dalam Mengidentifikasi Urgensi Wisata Religi. Prossiding Seminar Nasional Fakultas Ilmu Tarbiyan dan Keguruan UIN Syarif Hidayatullah Jakarta

Oktaviani, Meri, Rihlah Nur Aulia, dan Sari Narulita. 2018. Telaah Literasi Digital dalam Mengidentifikasi Minat Masyarakat terhadap Wisata Religi di Jakarta. Prossiding Seminar Nasional Fakultas Ilmu Tarbiyan dan Keguruan UIN Syarif Hidayatullah Jakarta 
Lingua Rima: Jurnal Pendidikan Program Studi Bahasa dan Sastra Indonesia

Vol. 9 No. 1 Juli 2020

Windarti, Anissa. 2018. Literasi Digital dan Perilaku Kecurangan Akademik dalam Dimensi Fraud Triangle. Prossiding Seminar Nasional Fakultas Ilmu Tarbiyan dan Keguruan UIN Syarif Hidayatullah Jakarta 